\section{Production of Three Eastern U.S. Native Shrubs: Effects of Auxin Concentration on Rooting and Shade Level on Container Plant Growth}

\author{
Jessica D. Lubell ${ }^{1}$ and Jacob A. Griffith Gardner
}

ADDITIONAL INDEX WORDS. american fly honeysuckle, Lonicera canadensis, hobblebush, Viburnum lantanoides, sweetbells, Eubotrys racemosa, chlorophyll fluorescence, leaf color

$\overline{\text { SUMMARY. American fly honeysuckle (Lonicera canadensis), hobblebush (Viburnum }}$ lantanoides), and sweetbells (Eubotrys racemosa) are eastern U.S. native shrubs with ornamental value, which might become successful nursery crops if they propagate readily from stem cuttings and grow uniformly in containers. We evaluated rooting success for hobblebush and sweetbells using stem cuttings treated with indole-3butyric acid (IBA) in talc at concentrations of $0,1000,3000$, or $8000 \mathrm{ppm}$. For hobblebush, IBA at 1000,3000 , or $8000 \mathrm{ppm}$ will yield $70 \%$ rooting success. For sweetbells, IBA treatment did not enhance rooting, and $88 \%$ rooting success can be achieved with untreated cuttings. Stem cuttings of american fly honeysuckle root at 49\% (previously published). We also evaluated all three native shrubs grown in nursery trade \# 1 containers under shade levels of $0 \%, 40 \%$, or $70 \%$. American fly honeysuckle grown under $40 \%$ or $70 \%$ shade were larger, had a greener hue angle, and higher chlorophyll fluorescence $(\mathrm{Fv} / \mathrm{Fm})$ than plants grown in full sun.

Throughout the study period, Fv/Fm values for full-sun american fly honeysuckle were 0.6 or below, indicating plants were stressed. Hobblebush in $40 \%$ and $70 \%$ shade were wider, had more leaves, and enhanced foliage color compared with fullsun plants. Hobblebush in $70 \%$ had the highest $\mathrm{Fv} / \mathrm{Fm}$ values at 0.78 or higher across the study period. For sweetbells, plant width increased as shade level increased. Even though sweetbells in $70 \%$ shade were wider and larger, they lacked density and had a less appealing habit than $40 \%$ shade and full-sun plants. Of the three study species, sweetbells might be the easiest plant for growers to incorporate into production because it propagates readily from stem cuttings and can be grown in full sun to $40 \%$ shade. Hobblebush and american fly honeysuckle may present more challenges for growers because hobblebush requires considerable shade to grow and american fly honeysuckle is more difficult to propagate.

$\mathrm{T}$ here is increased interest among ornamental plant growers to identify native shrubs that can be produced commercially for the nursery and landscape industry. $\mathrm{Na}$ tive shrubs must propagate readily from stem cuttings because this method yields uniform plants. In addition, plants must grow well in containers to become a successful commercial crop. Three eastern U.S. native deciduous shrubs with ornamental potential for landscape use are american fly honeysuckle, hobblebush, and sweetbells.

American fly honeysuckle is native from New Brunswick to Manitoba

Department of Plant Science and Landscape Architecture, University of Connecticut, Storrs, CT 06269

We thank Bryan Connolly for help in locating plant material.

${ }^{1}$ Corresponding author. E-mail: Jessica.lubell@uconn. edu.

doi: 10.21273/HORTTECH03652-17 in Canada, and south to Connecticut, Pennsylvania, and Michigan (Hightshoe, 1988). Plants have a multistemmed low-mounded habit, grow 2 to $5 \mathrm{ft}$ in height, and have lime green summer foliage. Plants are especially useful for their early spring tubular yellow flowers and adaptability to dry, shaded locations. Stem cuttings taken from May to June and treated with 3000 ppm IBA root at $49 \%$ (Cartabiano and Lubell, 2013). Small liner plants require lower fertility levels than established containers of trade \#l size or larger (Lubell and Shrestha, 2016).

Hobblebush is native from New Brunswick to Ontario in Canada, and south to Connecticut, northern Pennsylvania, and the mountains of North Carolina (Hightshoe, 1988). Plants grow 6 to $12 \mathrm{ft}$ in height, are rhizomatous, and sucker to produce a loose colony of stems with tiered branching. The large, 3 to 5 -inch diameter, heart-shaped leaves are medium to dark green in summer and transition to deep red in fall (Dirr, 2009). This shrub is highly sought after for its robust foliage and large (3 to 5-inch diameter), white, lace-cap inflorescences, but supplies of the plant are constrained by a myriad of propagation difficulties (Dirr and Heuser, 1987).

The native range of sweetbells begins in southern Massachusetts and extends south along the U.S. Atlantic coast and then west to Louisiana (Dirr, 2009). Plants have an upright, multistemmed, suckering habit and grow 4 to $6 \mathrm{ft}$ in height. Leaves emerge with a reddish cast before turning bright green in summer and then often a vibrant, scarlet red in fall. They are small, white, urn-shaped flowers that produce a slight fragrance and are held on 2 to 4-inch-long, one-sided terminal racemes. Sweetbells has proven to be highly adaptable to dry and exposed landscape conditions and exhibits a high level of white-tailed deer (Odocoileus virginianus) resistance (Shrestha and Lubell, 2015).

There are no published reports about softwood stem-cutting propagation of hobblebush and sweetbells; therefore, we evaluated the impact of increasing concentration of rooting hormone on softwood stem cutting success for these two native species.

\begin{tabular}{llll}
\hline $\begin{array}{l}\text { Units } \\
\text { To convert U.S. to SI, } \\
\text { multiply by }\end{array}$ & U.S. unit & SI unit & $\begin{array}{l}\text { To convert SI to U.S., } \\
\text { multiply by }\end{array}$ \\
\hline 0.3048 & $\mathrm{ft}$ & $\mathrm{m}$ & 3.2808 \\
2.54 & inch(es) & $\mathrm{cm}$ & 0.3937 \\
16.3871 & inch & $\mathrm{cm}^{3}$ & 0.0610 \\
1 & $\mathrm{mmho} / \mathrm{cm}$ & $\mathrm{mS} \cdot \mathrm{cm}^{-1}$ & 1 \\
28.3495 & $\mathrm{oz}$ & $\mathrm{g}$ & 0.0353 \\
37.0798 & $\mathrm{oz} / \mathrm{yard}$ & $\mathrm{g} \cdot \mathrm{m}^{-3}$ & 0.0270 \\
1 & $\mathrm{ppm}$ & $\mathrm{mg} \cdot \mathrm{L}^{-1}$ & 1 \\
0.9464 & $\mathrm{qt}$ & $\mathrm{L}$ & 1.0567 \\
$\left({ }^{\circ} \mathrm{F}-32\right) \div 1.8$ & ${ }^{\circ} \mathrm{F}$ & ${ }^{\circ} \mathrm{C}$ & $\left({ }^{\circ} \mathrm{C} \times 1.8\right)+32$
\end{tabular}

Hortlechnology · June $201727(3)$ 
Because american fly honeysuckle, hobblebush, and sweetbells are primarily considered to be understory shrubs (Dirr, 2009), an additional objective of this study was to evaluate plant growth and performance in containers under increasing levels of shade. Shading during production may improve foliar coloration and maintain a cooler root zone, which is beneficial for plant growth and appearance (Brand, 1997). Other studies looking at plants that naturally grow in shade such as golden hakone grass (Hakonechloa macra 'Aureola') and mountain laurel (Kalmia latifolia) have shown benefits of using shade in production (Brand, 1997; Harvey and Brand, 2002). Growers typically use shade of $30 \%$ to $40 \%$ and $60 \%$ to $70 \%$ depending on the crops they are growing and the geographic location of production.

\section{Materials and methods}

Propagation. This study was conducted in 2013 and repeated in 2014. Softwood stems sweetbells were collected from mature, containerized stock plants grown at the University of Connecticut (UConn) Plant Science Research and Education Facility in Storrs, CT, on 12 June 2013 and 24 June 2014. Plant material was collected in early morning and processed immediately after collection into terminal cuttings 4 to 5 inches in length with four to six nodes. Cuttings were wounded twice on opposite sides and dipped in talcbased IBA rooting hormone at 0 , 1000,3000 , or 8000 ppm [Hormo$\operatorname{din}^{\circledR} \# 1$, \#2, or \#3, respectively (OHP, Mainland, $\mathrm{PA})]$ and inserted into 1.4 -qt plastic flats $(2.5 \times 6 \times 6.5$ inches) filled with medium composed of two parts Canadian sphagnum peatmoss (Fafard, Agawam, MA), one part horticultural-grade vermiculite (Whittmore Co., Lawrence, MA), and one part horticultural-grade perlite (Whittmore Co.). Control cuttings were wounded as described but not treated with rooting hormone. An experimental unit consisted of a flat with six cuttings and there were five flats (or replications) per hormone concentration. Flats of cuttings were arranged in a randomized complete block design and held on a polyethylene-covered hoop house bench under intermittent mist that provided $10 \mathrm{~s}$ of mist every $6 \mathrm{~min}$. The irrigation water had a $\mathrm{pH}$ of 5.9 and an EC of $21 \mathrm{mS} \cdot \mathrm{m}^{-1}$. Light level at cutting canopy was $\approx 285 \mu \mathrm{mol} \cdot \mathrm{m}^{-2} \cdot \mathrm{s}^{-1}$ photosynthetically active radiation $(P A R)$ measured on a cloudless day in July using a line quantum sensor (LI-COR, Lincoln, NE) and a quantum photometer (LI-189, LI-COR). After 8 weeks, cuttings were harvested and experimental units were evaluated for percentages of rooted cuttings. Root count (the number of roots 0.20 inch long or longer) and root length (the average of the three longest roots) for the rooted cuttings in an experimental unit were averaged to obtain a value for each experimental unit.

Softwood stem material of hobblebush was collected from mature plants near Adams, MA, on 20 June 2013 and 25 June 2014. Plant material of hobblebush was collected in early morning and placed in plastic bags in a chilled ice chest for transport to the UConn Plant Science Research and Education Facility where it was processed, within $4 \mathrm{~h}$ of collection, into terminal cuttings 2 to 3 inches in length with a single node. Cutting wounding and treatment with talcbased IBA rooting hormone were conducted as described for sweetbells. Cuttings were inserted in rows into 22.8 -qt plastic flats $(4.5 \times 14 \times$ 21 inches) filled with the same medium as used for sweetbells. Rows were assigned to hormone concentration using a randomized complete block design. An experimental unit consisted of a single row with five cuttings, and each flat contained four

Table 1. Rooting percentage, root count, and root length for softwood cuttings of hobblebush and sweetbells made in 2013 and 2014 and treated with talcbased indole-3-butyric acid (IBA) at 0, 1000, 3000, or $8000 \mathrm{ppm}$.

\begin{tabular}{|c|c|c|c|}
\hline$\underline{\mathrm{IBA}}(\mathrm{ppm})^{\mathrm{z}}$ & Rooting (\%) & Roots (no.) & Root length (inches) ${ }^{x}$ \\
\hline \multicolumn{4}{|l|}{ Hobblebush } \\
\hline 0 & $51.1 \mathrm{~b}^{\mathrm{w}}$ & $15.7 \mathrm{~b}$ & $4.0 \mathrm{~b}$ \\
\hline 1000 & $73.1 \mathrm{a}$ & $21.7 \mathrm{a}$ & $4.9 \mathrm{a}$ \\
\hline 3000 & $70.0 \mathrm{a}$ & $23.1 \mathrm{a}$ & $5.0 \mathrm{a}$ \\
\hline 8000 & $73.3 \mathrm{a}$ & $23.6 \mathrm{a}$ & $4.8 \mathrm{a}$ \\
\hline \multicolumn{4}{|l|}{ Sweetbells } \\
\hline 0 & $88.3 \mathrm{a}$ & $10.2 \mathrm{a}$ & $2.9 \mathrm{ab}$ \\
\hline 1000 & $76.7 \mathrm{~b}$ & $10.0 \mathrm{a}$ & $3.1 \mathrm{a}$ \\
\hline 3000 & $78.3 \mathrm{~b}$ & $10.8 \mathrm{a}$ & $2.9 \mathrm{ab}$ \\
\hline 8000 & $71.7 \mathrm{~b}$ & $10.4 \mathrm{a}$ & $2.8 \mathrm{~b}$ \\
\hline $\begin{array}{l}{ }^{\mathrm{z}} 1 \mathrm{ppm}=1 \mathrm{mg} \cdot \\
{ }^{\mathrm{y}} \text { Root count is } \mathrm{t} \\
{ }^{\mathrm{x}} \text { Root length is } \\
{ }^{\mathrm{w}} \text { Mean separati } \\
\text { difference at } P \leq\end{array}$ & $\begin{array}{l}\text { roots longer th } \\
\text { the three long } \\
\text { umns, within }\end{array}$ & 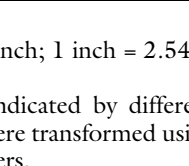 & $\begin{array}{l}\text { by Fisher's least significant } \\
\text { and reported table values for }\end{array}$ \\
\hline
\end{tabular}

rows, hence each flat represented a replication. There were five flats (or replications). Flats of cuttings were placed under intermittent mist as described for sweetbells. After 8 weeks, cuttings were harvested and data were collected as described for sweetbells.

Rooting percentage, root count, and root length data were subjected to analysis of variance [ANOVA (PROC MIXED)] and mean separation using Fisher's least significant difference test $(P \leq 0.05)$ using SAS (version 9.4 for Windows; SAS Institute, Cary, NC). There was no significant difference between years, so the data from both years were combined for statistical analysis, resulting in 10 replications per treatment for both species. For mean separation, rooting percent data were transformed using arcsine.

Shade. This study was conducted outdoors in a gravel-surfaced container nursery at the UConn Plant Science Research and Education Facility in 2015 and repeated in 2016. Two-year-old uniform liners of american fly honeysuckle, hobblebush, and sweetbells grown in 0.32-qt containers were transplanted into $3.2-\mathrm{qt}$ (trade \#1) containers on 5 May 2015 and 28 Apr. 2016. At the time of transplanting, liner plants of american fly honeysuckle averaged 17 inches tall, 14 inches wide, and had 12 shoots; hobblebush averaged 8 inches tall, 9 inches wide, and had 3 shoots and 10 leaves; and sweetbells averaged 8 inches tall, 5 inches wide, and had 9 shoots. The growth medium 
Table 2. Height, width, size, number of shoots and leaves, and shoot and root dry weight for plants of american fly honeysuckle, hobblebush, and sweetbells grown in trade \# 1 containers under shade levels of $0 \%, 40 \%$, or $70 \%$ for $90 \mathrm{~d}$ in 2015 and $97 \mathrm{~d}$ in 2016.

\begin{tabular}{|c|c|c|c|c|c|c|c|c|}
\hline Species & Shade (\%) & $\begin{array}{c}\mathrm{Ht} \\
\text { (inches) }^{\mathrm{z}}\end{array}$ & $\begin{array}{l}\text { Width } \\
\text { (inches) }^{\mathrm{y}}\end{array}$ & $\begin{array}{c}\text { Size } \\
\left(\text { inch }^{3}\right)^{x}\end{array}$ & $\begin{array}{c}\text { Shoots } \\
\text { (no./plant) }\end{array}$ & $\begin{array}{c}\text { Leaves } \\
\text { (no./plant) }\end{array}$ & Shoot dry wt (g/plant $)^{w}$ & $\begin{array}{l}\text { Root dry wt } \\
\text { (g/plant) }\end{array}$ \\
\hline \multicolumn{9}{|c|}{ American fly honeysuckle } \\
\hline & 0 & $20.2 \mathrm{a}^{\mathrm{v}}$ & $16.1 \mathrm{~b}$ & $5,678.9 \mathrm{~b}$ & $11.1 \mathrm{a}$ & $\mathrm{N} / \mathrm{A}$ & $27.4 \mathrm{a}$ & $42.0 \mathrm{a}$ \\
\hline & 40 & $24.6 \mathrm{a}$ & $18.4 \mathrm{a}$ & $9,890.3 \mathrm{a}$ & $11.5 \mathrm{a}$ & $\mathrm{N} / \mathrm{A}$ & $27.3 \mathrm{a}$ & $65.4 \mathrm{a}$ \\
\hline & 70 & $27.6 \mathrm{a}$ & $19.3 \mathrm{a}$ & $11,164.4 \mathrm{a}$ & $9.9 \mathrm{a}$ & $\mathrm{N} / \mathrm{A}$ & $23.1 \mathrm{a}$ & $44.2 \mathrm{a}$ \\
\hline \multicolumn{9}{|c|}{ Hobblebush } \\
\hline & 70 & $13.0 \mathrm{a}$ & $11.9 \mathrm{a}$ & $2,127.7 \mathrm{a}$ & $3.4 \mathrm{a}$ & $15.7 \mathrm{a}$ & $12.5 \mathrm{a}$ & $8.3 \mathrm{a}$ \\
\hline \multicolumn{9}{|c|}{ Sweetbells } \\
\hline & 0 & $18.6 \mathrm{a}$ & $10.9 \mathrm{c}$ & $2,211.6 \mathrm{~b}$ & $10.1 \mathrm{a}$ & $\mathrm{N} / \mathrm{A}$ & $22.9 \mathrm{a}$ & $64.0 \mathrm{a}$ \\
\hline & 40 & $19.8 \mathrm{a}$ & $13.3 \mathrm{~b}$ & $3,492.7 \mathrm{~b}$ & $11.8 \mathrm{a}$ & $\mathrm{N} / \mathrm{A}$ & $23.1 \mathrm{a}$ & $64.6 \mathrm{a}$ \\
\hline & 70 & $24.6 \mathrm{a}$ & $17.9 \mathrm{a}$ & $7,823.6 \mathrm{a}$ & $11.7 \mathrm{a}$ & $\mathrm{N} / \mathrm{A}$ & $25.1 \mathrm{a}$ & $78.9 \mathrm{a}$ \\
\hline
\end{tabular}

${ }^{\mathrm{z}} 1$ inch $=2.54 \mathrm{~cm}$.

yPlant width was measured twice, at right angles to each measurement, and averaged.

${ }^{x}$ Plant size was the product of height and two perpendicular widths; 1 inch ${ }^{3}=16.3871 \mathrm{~cm}^{3}$.

${ }^{\mathrm{w}} \mathrm{l} \mathrm{g}=0.0353 \mathrm{oz}$.

${ }^{\mathrm{v}}$ Mean separation within columns, within species, indicated by different letters, by Fisher's least significant difference at $P \leq 0.05(n=20)$.

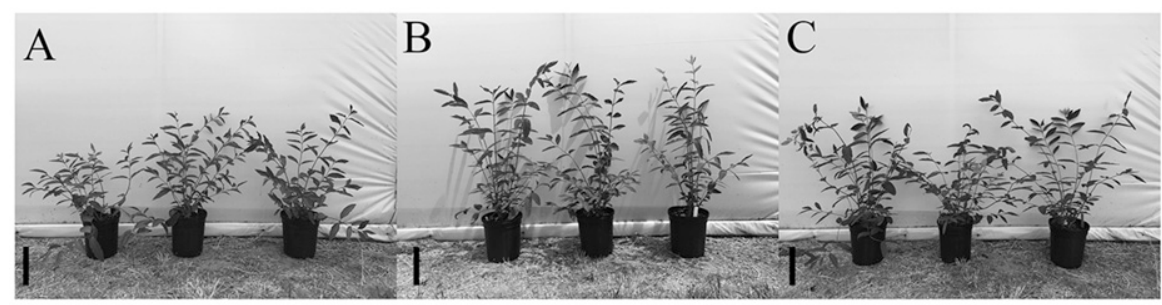

american fly honeysuckle

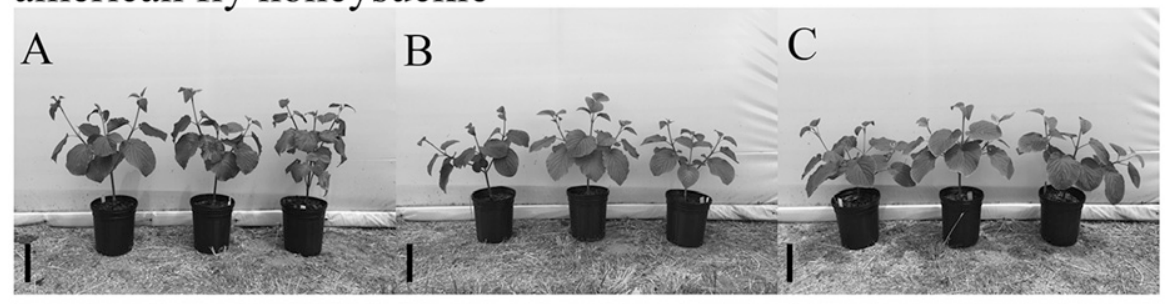

hobblebush

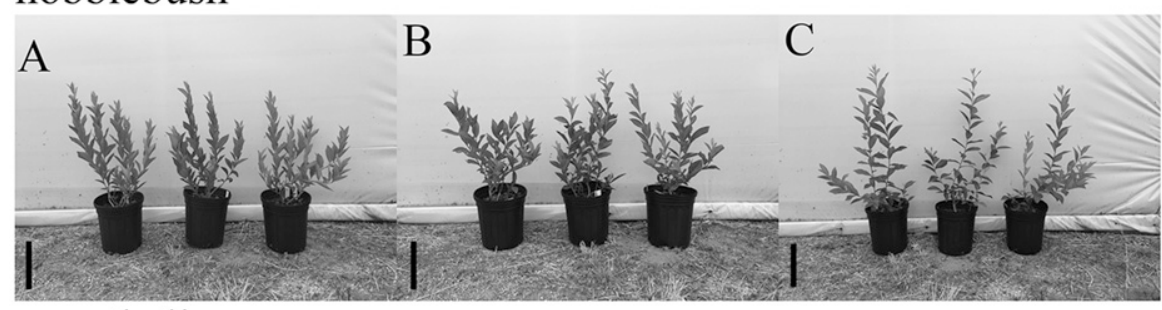

sweetbells

Fig. 1. Photographs of trade \# 1 containers of american fly honeysuckle, hobblebush, and sweetbells grown under shade levels of $0 \%(\mathrm{~A}), 40 \%(\mathrm{~B})$, or $70 \%(\mathrm{C})$. Scale bars equal 6.5 inches $(16.51 \mathrm{~cm})$.

composed of four parts of aged pine bark (Fafard), two parts of Canadian sphagnum peatmoss (Fafard), and one part of sand amended with dolomitic lime at $24 \mathrm{oz} / \mathrm{yard}^{3}$. After transplanting, containers were top-dressed with controlled-release fertilizer (Osmocote Pro 20N-1.7P$5.8 \mathrm{~K} 8$ to 9 month formulation; Everris NA, Dublin, $\mathrm{OH}$ ) at $0.4 \mathrm{oz}$ per plant. Irrigation was provided during the growing season by trickle emitters at the rate of $0.85 \mathrm{qt} / \mathrm{d}$. Shade was provided by covering sections (16 ft long) of metal hoop house ( $8 \mathrm{ft}$ high, $48 \mathrm{ft}$ long, $17 \mathrm{ft}$ wide) with woven polypropylene cloth. Shade densities provided by the cloth were verified in April using a line quantum sensor (LI-COR) and a quantum photometer (LI-189, LICOR), and were determined to be $70 \%$ (about $390 \mu \mathrm{mol} \cdot \mathrm{m}^{-2} \cdot \mathrm{s}^{-1} \mathrm{PAR}$ ) and $40 \%$ (about $765 \mu \mathrm{mol} \cdot \mathrm{m}^{-2} \cdot \mathrm{s}^{-1}$ $P A R)$. No shadecloth was provided for the full-sun treatment. The experimental design was a split-plot with shade as the fixed main plot. Within each main plot, there was a randomized complete block arrangement with 10 blocks each comprised of one plant of each species. Plants were placed in shade from 14 May to 12 Aug. in 2015 (90 d) and 3 May to 8 Aug. in 2016 (97 d).

Chlorophyll fluorescence was measured biweekly from 26 May 2015 (week 21) to 4 Aug. 2015 (week 31) using a fluorometer [Plant Efficiency Analyzer (PEA); Hansatech Instruments, Norfolk, England] for four randomly selected plants per species per shade level. For each plant, three $\mathrm{Fv} / \mathrm{Fm}$ measurements were taken using different leaves of similar age, and these values were averaged for each plant. The same leaves (marked with small tags) and plants were recorded over the 10-week measuring period. Leaves were dark-adapted for 15 min using the manufacturer's leaf clips before measuring. Soil temperature was measured biweekly from weeks 21 to 
31 in 2015 and 2016 using a moisture meter (WET Sensor type WET-2 and $\mathrm{HH} 2$; Delta-T Devices, Cambridge,

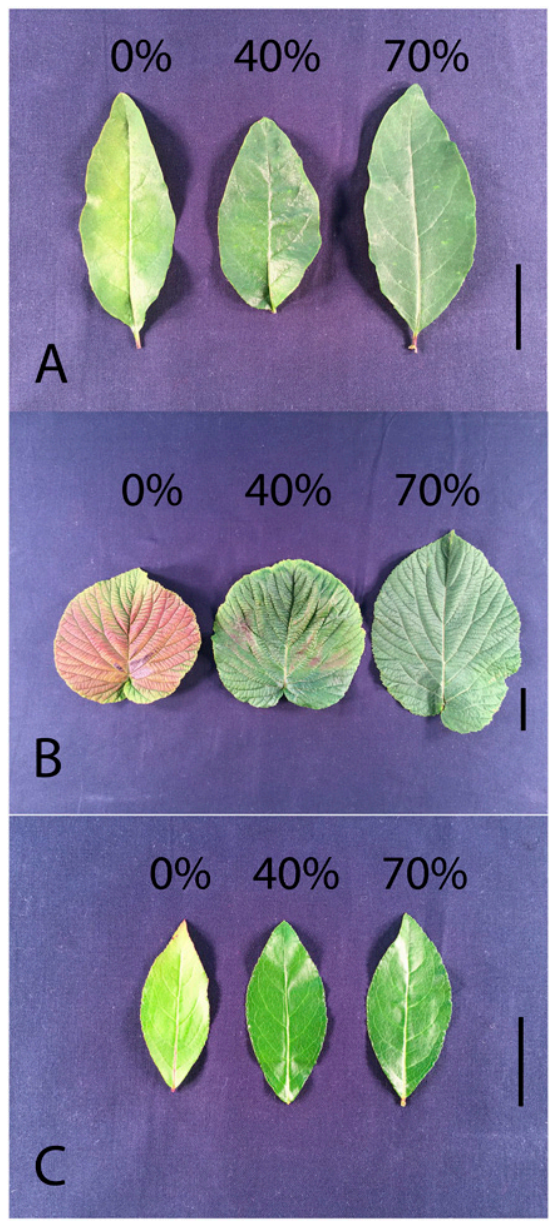

Fig. 2. Photographs of leaves of american fly honeysuckle (A), hobblebush (B), and sweetbells (C) grown under shade levels of $0 \%, 40 \%$, or $70 \%$. Scale bars equal 1 inch $(2.54 \mathrm{~cm})$.

Table 3. Foliar CIELAB (Vienna, Austria) coordinates for plants of american fly honeysuckle, hobblebush, and sweetbells grown in trade \#1 containers under shade levels of $0 \%, 40 \%$, or $70 \%$ for $97 \mathrm{~d}$ in 2016 .

\begin{tabular}{|c|c|c|c|c|}
\hline Species & Shade (\%) & $\mathrm{L}^{* \mathrm{z}}$ & Chroma & Hue angle \\
\hline \multicolumn{5}{|c|}{ American fly honeysuckle } \\
\hline & 0 & $34.3 \mathrm{a}^{\mathrm{y}}$ & $19.6 \mathrm{a}$ & $123.5 \mathrm{~b}$ \\
\hline & 40 & $31.2 \mathrm{a}$ & $14.1 \mathrm{a}$ & $132.4 \mathrm{a}$ \\
\hline & 70 & $30.5 \mathrm{a}$ & $13.4 \mathrm{a}$ & $133.7 \mathrm{a}$ \\
\hline \multicolumn{5}{|c|}{ Hobblebush } \\
\hline & 0 & $36.2 \mathrm{a}$ & $23.5 \mathrm{a}$ & $85.3 \mathrm{~b}$ \\
\hline & 40 & $31.8 \mathrm{a}$ & $20.7 \mathrm{a}$ & $134.9 \mathrm{a}$ \\
\hline & 70 & $38.0 \mathrm{a}$ & $20.2 \mathrm{a}$ & $128.9 \mathrm{a}$ \\
\hline \multicolumn{5}{|c|}{ Sweetbells } \\
\hline & 0 & $36.6 \mathrm{a}$ & $22.6 \mathrm{a}$ & $128.5 \mathrm{a}$ \\
\hline & 40 & $35.3 \mathrm{a}$ & $18.3 \mathrm{a}$ & $129.8 \mathrm{a}$ \\
\hline & 70 & $36.3 \mathrm{a}$ & $18.0 \mathrm{a}$ & $129.5 \mathrm{a}$ \\
\hline
\end{tabular}

${ }^{\mathrm{z}} \mathrm{L}^{*}$ is the value of a color and quantifies the lightness or darkness of a color.

${ }^{\mathrm{y}}$ Mean separation within columns, within species, indicated by different letters, by Fisher's least significant difference at $P \leq 0.05(n=4)$.

England) for 12 randomly selected plants (four plants per species) per shade level. On 2 Aug. 2016 (week 31 ), leaf color was analyzed for four randomly selected plants per species per shade level using a colorimeter (CR-400 Chroma Meter; Konica Minolta Sensing Americas, Ramsey, NJ) connected to a data processor (DP-400; Konica Minolta Sensing Americas). For each plant, three Commission Internationale de l'Eclairage (CIELAB, Vienna, Austria), lightness, red-green axis, blue-green axis measurements were taken using different leaves of similar age, and these values were averaged for each plant. Lightness $\left(L^{*}\right)$, red-green axis $\left(a^{*}\right)$, and bluegreen axis $\left(b^{*}\right)$ were measured at the midpoint between the distal and basal leaf ends. Leaf midribs were excluded from the sampling area. The colorimeter was calibrated at illuminant $C$ with a white standard. Owing to the slightly translucent nature of the plant leaf tissue, a standard white background was placed behind each leaf when a CIELAB measurement was taken (Little, 1964). In addition to the CIELAB coordinated value, $L^{*}$, the coordinates of hue angle $\left(\tan -1 b^{*} /\right.$ $\left.a^{*}\right)$ and chroma $\left(a^{*} 2+b^{*} 2\right)$ were calculated from $a^{*}$ and $b^{*}$. During the second week of August of both years, plants were destructively harvested, and plant height and width, number of shoots, and shoot and root dry weights were recorded. The number of leaves was counted for hobblebush. Plant height was measured from substrate surface to the apex of the foliage. Plant width was measured twice, at right angles to each measurement. Plant size was then calculated by multiplying height $x$ width $1 \times$ width 2 . Root harvest was accomplished by unpotting the plants, shaking the potting media from the roots and washing the roots. Shoots and roots were dried at $70{ }^{\circ} \mathrm{C}$ for about $72 \mathrm{~h}$ and weighed.

Plant-harvest and leaf-color data were subjected to ANOVA (PROC MIXED) and mean separation using Fisher's least significant difference test $(P \leq 0.05)$ using SAS (version 9.4 for Windows). There was no significant difference between years, so the plantharvest data from both years were combined for statistical analysis.

\section{Results and discussion}

For hobblebush, all IBA treatments increased rooting percent, root count, and root length above that obtained without IBA treatment (Table 1 ). IBA yielded rooting percentages $(70-73 \%)$ that would be acceptable for commercial production, especially for a plant where there is high demand. Plants must be able to be propagated at $50 \%$ rooting success to be considered a viable commercial nursery crop (Cumming, 1976); however most propagators strive for closer to $80 \%$ rooting success ( $S$. Ruffino, personal communication).

For sweetbells, treatment of cuttings with IBA hormone reduced rooting, whereas untreated cuttings rooted at $88 \%$ (Table 1 ). These findings suggest that there is no production advantage in using IBA hormone, and growers may consider not spending money on a hormone treatment. Cartabiano and Lubell (2013) and Lubell (2013) previously showed that four northeastern U.S. native shrub species could be propagated at commercially viable levels, and these findings add to that list of potential new ornamental native shrub crops.

American fly honeysuckle plants grown in $40 \%$ and $70 \%$ shade had significantly greater plant width and size than plants grown in full sun (Table 2; Fig. 1). Plant height, number of shoots per plant, and shoot and root dry weights were unaffected by shade (Fig. 1). Overall the leaves on american fly honeysuckle plants in full sun were bleached out and yellow-green in appearance (Fig. 2). This observation was confirmed by 

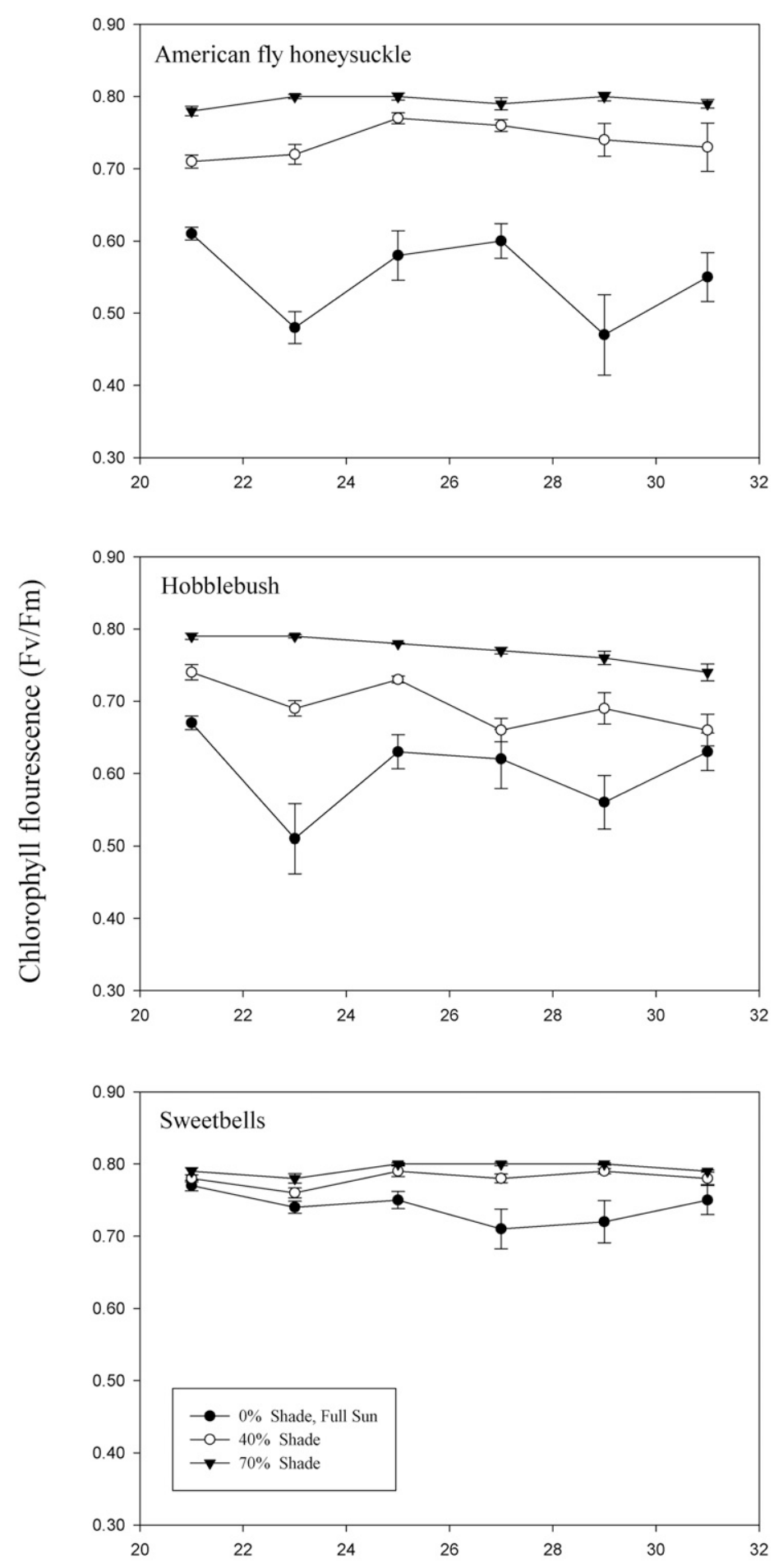

Week of the year

Fig. 3. Chlorophyll fluorescence (Fv/Fm) in 2015 for american fly honeysuckle, hobblebush, and sweetbells grown under shade levels of $0 \%, 40 \%$, or $70 \%$. Vertical bars indicate \pm 1 SE $(n=4)$.

measurements of leaf color (Table 3 ) and $\mathrm{Fv} / \mathrm{Fm}$ data (Fig. 3). American fly honeysuckle plants in $40 \%$ and $70 \%$ shade had a greener hue angle than full-sun plants, which had a more yellow-green hue angle (Table 3 ). There were no significant differences shown with several horticultural crops including landscape ornamentals such as douglas-fir [Pseudotsuga menziesii (Fisker et al., 1995)], rose [Rosa (Genoud et al., 1999)], sedum [Sedum (Durhman et al., 2006)], and yew [Taxus (Bruce et al., 2001)]. In our study, $\mathrm{Fv} / \mathrm{Fm}$ values ranged from 0.78 to 0.80 for plants of american fly honeysuckle grown in $70 \%$ shade and 0.71 to 0.75 for plants grown in $40 \%$ shade, and measurements did not vary much across the study period (Fig. 3). $\mathrm{Fv} / \mathrm{Fm}$ measures for american fly honeysuckle plants grown in full sun were around 0.60 or below and as low as 0.46 , and measurements were more variable across the study period. In a study of peppers (Capsicum annuum) and cucumbers (Cucumis sativus), Eksi et al. (2015) reported that $\mathrm{Fv} / \mathrm{Fm}$ values of 0.70 to 0.80 indicate healthy plants. Plants with Fv/ Fm values of 0.6 or below have been characterized as experiencing stress (Ritchie, 2006). Fv/Fm and leafcolor data for american fly honeysuckle indicate that plants grown at $70 \%$ and $40 \%$ shade were healthier and had enhanced foliar color compared with plants grown in full sun.

Plants of hobblebush grown in full sun were not as wide and had fewer leaves than plants grown at $40 \%$ or $70 \%$ shade (Table 2 ). There was no significant difference in plant height, size, number of shoots (Fig. 1), and shoot and root dry weight for the different shade levels. Leaves in full sun turned yellow and red and occasionally developed necrotic patches (Fig. 2), which resulted in a dramatically reduced hue angle for full-sun plants compared with plants in shade (Table 3 ). Hobblebush plants grown in $70 \%$ shade had the highest Fv / Fm, whereas plants grown in $40 \%$ shade showed a decline in $\mathrm{Fv} / \mathrm{Fm}$ across the study period from 0.74 at the beginning of the study to 0.66 by the end of the study (Fig. 3). Fv/Fm values for plants in full sun were the most variable across the study period, dipping below 0.60 on two occasions. $\mathrm{Fv} / \mathrm{Fm}$ for full-sun plants was significantly lower than for plants in $40 \%$ shade for all measurements except at 27 and 31 weeks. As seen in american fly honeysuckle, hobblebush plants grown in $40 \%$ and $70 \%$ shade had enhanced foliage color compared with plants grown in full sun. Similar results have been reported for 


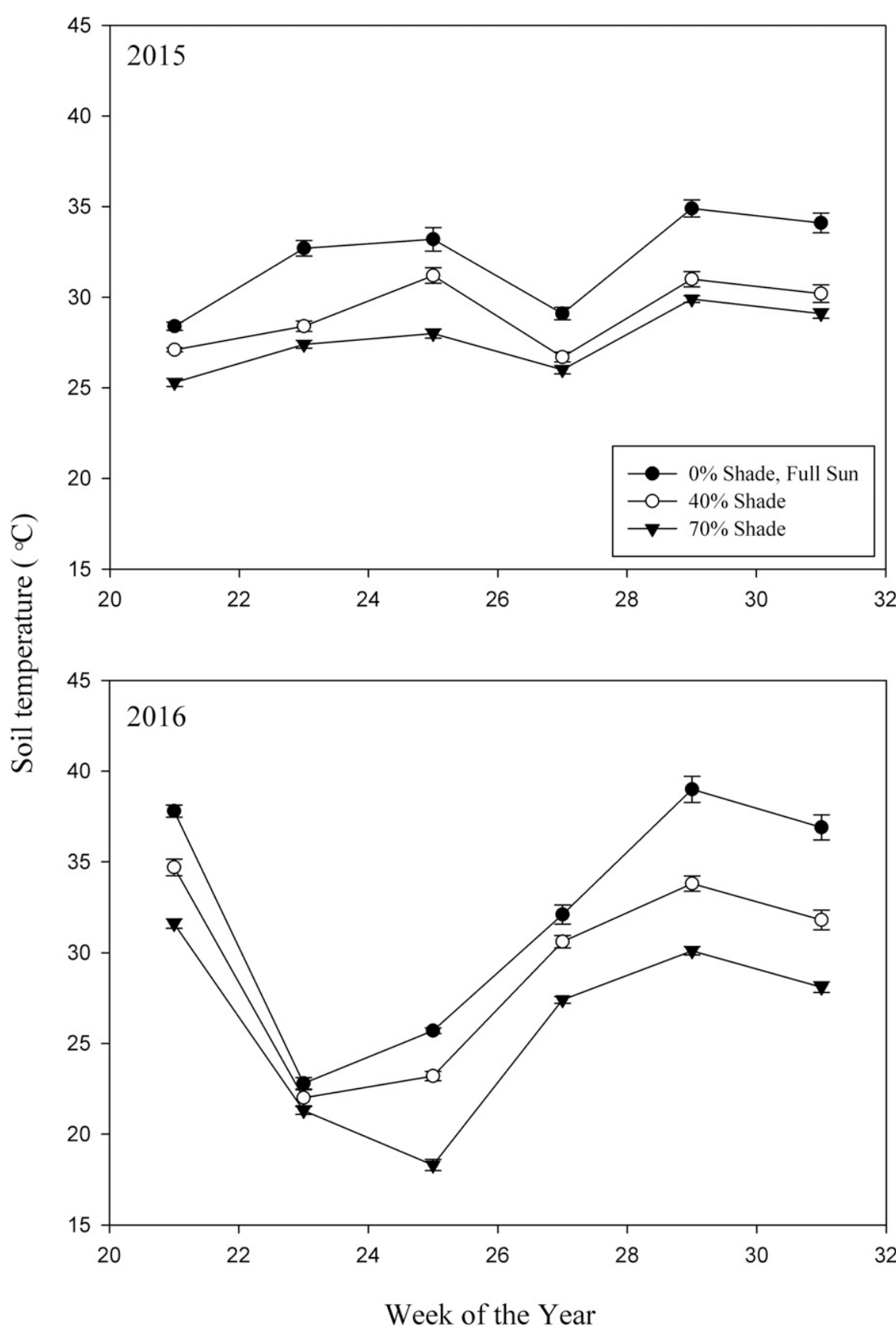

Fig. 4. Soil temperature $\left({ }^{\circ} \mathrm{C}\right)$ in 2015 and 2016 for american fly honeysuckle, hobblebush, and sweetbells plants grown under shade levels of $0 \%, 40 \%$, or $70 \%$. Vertical bars indicate \pm 1 SE $(n=12) ;\left(1.8 \times{ }^{\circ} \mathrm{C}\right)+32={ }^{\circ} \mathrm{F}$.

cultivars of mountain laurel, where plants grown at $40 \%$ and $60 \%$ shade had improved foliage color compared with plants grown in full sun (Brand, 1997).

Increased shading of sweetbells resulted in plants with greater width, and plant size was greater for $70 \%$ shade than for $40 \%$ shade and full sun (Table 2; Fig. 1). Similarly for golden hakone grass, increasing shading from $0 \%$ to $30 \%$ to $50 \%$ to $70 \%$ increased plant size, but at $70 \%$, plants had developed a visually less appealing open habit (Harvey and Brand, 2002). In our study, increased spread on sweetbells in $70 \%$ shade also resulted in a less dense and less attractive habit compared with plants in $40 \%$ shade and full sun (Fig. 1). There were no significant differences between shade levels for number of shoots per plant and shoot and root weight (Table 2). The differences in $\mathrm{Fv} / \mathrm{Fm}$ between the shade levels for sweetbells were not as dramatic as was seen for american fly honeysuckle and hobblebush, however, increasing shade leads to higher Fv/Fm values (Fig. 3). Throughout the study period, Fv/Fm was consistently high at 0.78 or above for $70 \%$ shade and 0.75 or above for $40 \%$ shade. Sweetbells in full sun had a lower Fv/Fm, but values never dropped below 0.72 . Foliage color did not vary among the different shade levels for sweetbells, although some leaves on full-sun plants, particularly those near the shoot tip, were lighter green or more yellow at the end of the study (Fig. 2). In a similar study looking at green-leaved genotypes of japanese barberry (Berberis thunbergii) grown under shade levels of $0 \%$ to $72 \%$, no differences in foliage color were observed (Lehrer and Brand, 2010). Our findings for leaf color of sweetbells were not surprising, because this species, like japanese barberry, is adaptable to both shaded and full-sun sites (Shrestha and Lubell, 2015).

As expected and documented by Mathers (2003), Markham (2010), and others, container media temperatures were lower in shaded treatments (Fig. 4). Therefore, one factor that may have contributed to differences in growth between the shade treatments is container media temperature. The species studied here are woodland plants, especially american fly honeysuckle and hobblebush, which typically grow in shaded areas with dappled sunlight where soils are cooler (Hightshoe, 1988).

In conclusion, shade levels of either $40 \%$ or $70 \%$ were appropriate for american fly honeysuckle. For hobblebush, both $40 \%$ and $70 \%$ shade levels produced healthy, vigorous plants, but $70 \%$ yielded visually more appealing plants. For sweetbells, 70\% shade was excessive, but $40 \%$ shade and full sun produced attractive plants. Growers should have no problems adopting sweetbells into container production because it is easy to propagate and can be grown in full sun or light shade. Hobblebush and american fly honeysuckle may present more challenges for growers. Hobblebush, although it can be propagated with good success, requires considerable shade to grow. American fly honeysuckle is adaptable to different shade levels but is more challenging to propagate. For growers that can only accommodate a single level of shading in production, shadecloth in the range 
of $40 \%$ would produce plants of market quality.

\section{Literature cited}

Brand, M.H. 1997. Shade influences plant growth, leaf color, and chlorophyll content of Kalmia latifolia L. cultivars. HortScience 32:206-208.

Bruce, S.E., D.B. Rowe, and J.A. Flore. 2001. Chlorophyll fluorescence and vegetative propagation of Taxus. HortScience 36:971-975.

Cartabiano, J.A. and J.D. Lubell. 2013. Propagation of four underused native species from softwood cuttings. HortScience 48:1018-1020.

Cumming, W.A. 1976. Evaluation and propagation of saskatons. Proc. Western Can. Soc. Hort. 25:76-80.

Dirr, M.A. 2009. Manual of woody landscape plants. 6th ed. Stipes Publ., Champaign, IL.

Dirr, M.A. and C.W. Heuser. 1987. The reference manual of woody plant propagation. Varsity Press, Athens, GA.

Durhman, A.K., D.B. Rowe, and C.L. Rugh. 2006. Effect of watering regimen on chlorophyll fluorescence and growth of selected green roof plant taxa. HortScience 41:1623-1628.

Eksi, M., D.B. Rowe, R. FernandezCanero, and B.M. Cregg. 2015. Effect of substrate compost percentage on green roof vegetable production. Urban For. Urban Green. 14:315-322.

Fisker, S., R. Rose, and D.L. Haase. 1995. Chlorophyll fluorescence as a measure of cold hardiness and freezing stress in $1+1$ douglas-fir seedlings. For. Sci. 41:564575 .

Genoud, C., A. Coudret, C. Amalric, and H. Sallanon. 1999. Effects of micropropagation conditions of rose shootlets on chlorophyl fluorescence. Photosynthetica 36:243-251.

Harvey, M.P. and M.H. Brand. 2002. Division size and shade density influence growth and container production of Hakonechloa macra Makino 'Aureola'. HortScience 37:196-199.

Hightshoe, G.L. 1988. Native trees, shrubs and vines for urban and rural America. Wiley, New York, NY.

Kraus, G.H. and E. Weis. 1991. Chlorophyll fluorescence and photosynthesis: The basics. Annu. Rev. Plant Physiol. Plant Mol. Biol. 42:313-349.

Lehrer, J.M. and M.H. Brand. 2010. Purple-leaved Japanese barberry (var. atropurpurea) genotypes become visually indistinguishable from green-leaved genotypes (Berberis thunbergii) at low light levels. J. Environ. Hort. 28:187-189.
Little, A.C. 1964. Color measurement of translucent food samples. J. Food Sci. 29:782-789.

Lubell, J.D. 2013. Softwood cutting propagation of northeast United States native shrub species. Proc. Intl. Plant Prop. Soc. 63:275-276.

Lubell, J.D. and P. Shrestha. 2016. Optimizing container production of American fly honeysuckle (Lonicera canadensis), beaked filbert (Corylus cornuta), and maple leaf viburnum (Viburnum acerifolium). Native Plants J. 17:39-45.

Markham, J.W. 2010. Color and shading of containers affects root-zone temperatures and growth of nursery plants. Kansas State Univ., Manhattan, MS Thesis.

Mathers, H.M. 2003. Summary of temperature stress issues in nursery containers and current methods of protection. HortTechnology 13:617-624.

Ritchie, G. 2006. Chlorophyll fluorescence: What is it and what do the numbers mean? U.S. Dept. For. Serv. Proc. 43:34-43.

Shrestha, P. and J.D. Lubell. 2015. Suitability of eight northeasetern U.S. native shrubs as replacements for invasive plants in a difficult landscape with whitetailed deer pressure. HortTechnology 25:171-176. 